\title{
Effects of temperature, water potential, and sodium chloride on Indiangrass germination
}

\author{
TIMOTHY E. FULBRIGHT
}

\section{Abatract}

Indlangrass [Sorghastrum nutans (L.) Nash] is widely used in range seeding. Objectives of this study were to determine the effects of temperature, water potential, and sodium chloride on germination of 'Lometa', 'Cheyenne', 'Llano', 'Oto', and 'Tejas' Indiangrass. Seeds were germinated at 6 alternating temperatures ranging from 5-15 to 30-40 C (12 hours-12 hours). Lometa, Cheyenne, and Tejas seeds were germinated in polyethylene glycol (mol. wt. = $8,000)$ solutions mixed to approximate water potentials of $0,-0.4$, $-0.8,-1.2$, and $-1.6 \mathrm{MPa}$ and in $0,0.06,0.12,0.18$, and $0.24 \mathrm{~mol}$

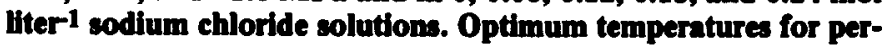
cent germination were 10-20 to 25-35, 10-20 to 20-30, and 15-25 and 20-30 C for Cheyenne and Tejas, Llano and Oto, and Lometa seeds, respectively. Percent germination of Cheyenne and Lometa seeds was reduced at water potentials of $-0.8 \mathrm{MPa}$ and lower, while Tejas seeds exhibited lower percent germination than controls at -1.2 and -1.8 MPa. Percent germination of Cheyenne and Lometa seeds was reduced by sodium chloride concentrations of $0.12 \mathrm{~mol}$ liter 1 and greater. Germination of Tejas seeds wes reduced at 0.18 and 0.24 mol liter-1. Indiangrass varieties appear to germinate within a similar range of temperatures but vary in germination response to low water potentials.

Key Words: Sorghastrum nutans, range seeding, ecophysiology, seed ecology, salinity

Indiangrass [Sorghastrum nutans (L.) Nash] is a native warmseason bunchgrass widely used in range seeding. 'Lometa' Indiangrass is a variety developed by the USDA Soil Conservation Service at Knox City, Texas, for use in central and southern Texas (Lorenz and Heizer 1982). Lometa is drought tolerant and produces forage yields almost twice that of 'Cheyenne' and 'Tejas' Indiangrass, 2 other varieties commonly planted in Texas, but has been difficult to establish in experimental plantings at the South Texas Plant Materials Center at Kingsville, Texas (Richard Heizer, SCS State Plant Materials Specialist, pers. commun.).

Success in artificial range seeding requires knowledge of many parameters, including optimum temperature and moisture conditions for germination (Sabo et al. 1979). Hsu et al. (1985) found that chilled 'IG-2C-F1' Indiangrass seeds germinated best at constant temperatures of 20 to $35^{\circ} \mathrm{C}$, while highest germination of unchilled seeds occurred between 12 and $15^{\circ} \mathrm{C}$. The Association of Official Seed Analysts (1970) recommends testing Indiangrass seeds at $20-30^{\circ} \mathrm{C}$ (16 hours-8 hours).

Germination is also affected by soil salinity. Soluble salts such as sodium chloride may reduce or prevent germination by direct ion effects or by lowering the osmotic potential of the soil solution (Young et al. 1983).

My objective was to determine the effects of 6 alternating temperature regimes, reduced water potentials, and sodium chloride on germination of Lometa Indiangrass. A second objective was to compare germination of Lometa with that of 4 other Indiangrass varieties commonly planted in the Southern Great Plains.

\footnotetext{
Author is associate professor, College of Agriculture and Home Economics, Campus Box 156, Texas A\&I University, Kingsville, Texas 78363 .

Research was funded by the Caesar Kleberg Wildlife Research Institute and the Houston Livestock Show and Rodeo. The author wishes to thank Dr. R. Bingham for assistance in statistical analyses and $\mathrm{K}$.S. Flenniken and Felipe Prieto for assistance in data collection.

Manuscript accepted 21 December 1987.
}

\author{
Materials and Methods
}

\section{General Methods}

Lometa Indiangrass seeds were obtained from the USDA-SCS Plant Materials Center at Knox City, Texas. Seeds used in temperature experiments were harvested in 1978 and those used in other experiments were harvested in 1981. Cheyenne (harvested in 1981), 'Llano' (harvest date unknown), 'Oto' (harvest date unknown), and Tejas (harvest date unknown) seeds were obtained from commercial sources. Seed viability was determined by soaking seeds in a $0.1 \% 2,3,5$-triphenyltetrazolium chloride solution at $30^{\circ} \mathrm{C}$ for 3 hours (Grabe 1970). Viability of Lometa seeds was $84 \%$ for seeds harvested in 1978 and $52 \%$ for seeds harvested in 1981 . Viability of Cheyenne, Llano, Oto, and Tejas seeds was $32,83,68$, and $62 \%$, respectively. Until used in experiments, seeds were stored in cloth bags at $15^{\circ} \mathrm{C}$ and $40 \%$ relative humidity. Temperature experiments were conducted in 1983 and other experiments were conducted in 1985.

Seeds were germinated on blotter paper (temperature experiments) or 2 layers of filter paper underlain by a layer of creped cellulose placed within 13.0 by 13.5 by $3.5 \mathrm{~cm}$ plastic boxes with tightly fitting lids. Seeds were treated with thiram [bis(dimethylthiocarbamoyl)disulfide] to minimize fungal growth.

Four plastic boxes arranged within controlled environment chambers in a randomized complete-block design were used as experimental units for each treatment and each experiment was repeated twice. Chambers were illuminated for 12 hours daily with cool-white fluorescent lights (photosynthetic photon flux density averaged $24 \mu \mathrm{mol} \mathrm{m}^{-2} \mathrm{~s}^{-1}$ ).

Seeds were considered germinated when radicles and shoots were $>4 \mathrm{~mm}$ long. Germinated seeds were counted daily for 28 days in the temperature experiments and at 5-day intervals for 20 days in other experiments. Germination rate (GR) was calculated by the equation of Maguire (1962). Corrected germination rate index (CGRI) was obtained by dividing GR by the final germination percentage and multiplying by 100 (Hsu et al. 1985).

\section{Temperature Enfects}

Effects of temperature on germination of the 5 varieties of Indiangrass were determined by germinating seeds at $5-15,10-20$, $15-25,20-30,25-35$, and $30-40^{\circ} \mathrm{C}(12$ hours of darkness -12 hours in light). Each plastic box contained 100 seeds and the substrata were moistened with $100 \mathrm{ml}$ of tap water.

Response curve analyses were used to determine the relationship between temperature and germination (Snedecor and Cochran 1967). Percent germination data were arcsine transformed before analysis, but untransformed data are reported in tables. Optimum temperatures for percent germination were defined as those temperatures for which mean percent germination was within the 95\% confidence interval of the maximum mean percent germination (Young et al. 1981). Optimum temperatures for CGRI were defined similarly.

\section{Water Potential and Sodium Chloride Effeets}

Seeds of Lometa, Cheyenne, and Tejas Indiangrass were germinated at $15-25^{\circ} \mathrm{C}$ (12 hours light-12 hours dark) on substrata moistened with $100 \mathrm{ml}$ polyethylene glycol (PEG) 8000 solutions mixed according to Michel (1983) to give water potentials of 0 , 
$-0.4,-0.8,-1.2$, and $-1.6 \mathrm{MPa}$. Since the water potential of PEG solutions may vary between PEG lots (Berkat and Briske 1982), samples of the solutions were sent to Dr. D. Kreig, Texas Tech University, for verification. Thermocouple psychrometer values for $-0.4,-0.8,-1.2$, and $-1.6 \mathrm{MPa}$ solutions were $-0.44 \pm 0.05$, $-0.88 \pm 0.17,-1.17 \pm 0.01$, and $-1.59 \pm 0.11 \mathrm{MPa}(\bar{x} \pm \mathrm{SD}, \mathrm{n}=$ 6). The pH of the PEG solutions ranged from 7.0 to 7.9, and the pH of distilled water averaged 6.0.

Seeds of the 3 Indiangrass varieties were also germinated on substrata moistened with sodium chloride $(\mathrm{NaCl})$ solutions of 0 , $0.06,0.12,0.18$, and 0.24 mol liter $^{-1}$. The $\mathrm{pH}$ of these solutions ranged from 5.8 to 6.4

In PEG and $\mathrm{NaCl}$ experiments, plastic boxes contained 50 seeds each and were sealed in plastic bags to inhibit evaporation. Radicle and shoot lengths of 2 randomly selected seedlings in each box were measured at the end of each experiment.

Response curve analyses were used to determine the relationship between water potential or $\mathrm{NaCl}$ concentration and percent germination, CGRI, radicle length, and shoot length (Snedecor and Cochran 1967). Percent germination data were arcsine transformed before analysis. Untransformed data are reported in tables. Fisher's protected LSDs were used to determine if germination at various levels of $\mathrm{PEG}$ or $\mathrm{NaCl}$ were significantly $(P<0.05)$ different from controls (distilled water). This test is appropriate when comparing each treatment mean with the control (Petersen 1985).

\section{Results}

\section{Temperature Effects}

Germination of each of the 5 Indiangrass varieties exhibited a quadratic response to temperature (Table 1). Optimum temperatures for percent germination were $10-20$ to $25-35^{\circ} \mathrm{C}$ for

Table 1. Means and standard deviations (in parentheses) for the effects of 6 alternating temperatures $\left({ }^{\circ} \mathrm{C}\right)$ on percent germination of 5 varietices of Indiangrass. Underlined means are within the $95 \%$ confidence interval of the maximum germination percentage for a variety.

\begin{tabular}{|c|c|c|c|c|c|}
\hline \multirow{2}{*}{$\begin{array}{l}\text { Temper- } \\
\text { ature }\end{array}$} & \multicolumn{5}{|c|}{ Variety } \\
\hline & Cheyenne & Llano & Lometa & Oto & Tejas \\
\hline $\begin{array}{r}5-15 \\
10-20\end{array}$ & $\begin{array}{l}11(8) \\
33(5)\end{array}$ & $\begin{array}{r}7(6) \\
65(5)\end{array}$ & $\begin{array}{l}24(18) \\
70(4)\end{array}$ & $\begin{array}{l}17(13) \\
53(8)\end{array}$ & $\begin{array}{l}16(9) \\
52(6)\end{array}$ \\
\hline $15-25$ & $33(5)$ & $66(6)$ & 75(3) & $53(4)$ & $53(6)$ \\
\hline $20-30$ & $32(7)$ & $62(2)$ & 74(5) & $49(4)$ & $49(4)$ \\
\hline $25-35$ & $30(4)$ & $54(8)$ & $60(3)$ & $39(3)$ & $47(7)$ \\
\hline $\begin{array}{l}30-40 \\
\text { Response } \\
\text { curve } \\
\text { relation- } \\
\text { ship } \\
R^{2}\end{array}$ & $\begin{array}{l}\text { Quadratic } \\
0.58^{* *}\end{array}$ & $\begin{array}{l}\text { Quadratic } \\
0.78^{* *}\end{array}$ & $\begin{array}{l}\text { Quadratic } \\
0.68^{* *}\end{array}$ & $\begin{array}{l}\text { Quadratic } \\
0.61 * *\end{array}$ & $\begin{array}{l}\text { Quadratic } \\
0.65^{* *}\end{array}$ \\
\hline
\end{tabular}

- Significant at $\mathbb{R}<0.01$.

Cheyenne and Tejas, $10-20$ to $20-30^{\circ} \mathrm{C}$ for Llano and Oto, and 15-25 and $20-30^{\circ} \mathrm{C}$ for Lometa seeds.

Corrected germination rate index of the 5 Indiangrass varieties increased yuadratically with increasing temperature (Table 2). Highest CGRI of Cheyenne and Oto seeds occurred at $30-40^{\circ} \mathrm{C}$. Optimum temperatures for CGRI were 25-35 and $30-40^{\circ} \mathrm{C}$ for Llano and Tejas seeds and $20-30$ to $30-40^{\circ} \mathrm{C}$ for Lometa seeds.

\section{Water Potential and Sodium Chloride Effects}

Percent germination of Cheyenne, Lometa, and Tejas seeds decreased quadratically with decreasing (more negative) water potential (Table 3). Germination of Tejas seeds was lower at water
Table 2. Means and standard deviations (in parentheses) for the effects of 6 alternating temperatures $\left({ }^{\circ}\right.$ C) on corrected zermination rate index (CGRI) of 5 varietles of Indiangraas. Underlined means are within the 95\% confidence interval of the maximum CGRI for a variety.

\begin{tabular}{llllll}
\hline \hline & \multicolumn{5}{c}{ Variety } \\
\cline { 2 - 6 } $\begin{array}{l}\text { Temper- } \\
\text { ature }\end{array}$ & Cheyenne & Llano & Lometa & \multicolumn{1}{c}{ Oto } & Tejas \\
\hline & & & $-\%$ & & \\
$5-15$ & $3.6(0.1)$ & $3.6(0.2)$ & $3.8(0.1)$ & $3.7(0.2)$ & $3.9(0.3)$ \\
$10-20$ & $7.1(0.8)$ & $6.5(0.5)$ & $6.4(0.2)$ & $6.6(0.4)$ & $7.1(0.4)$ \\
$15-25$ & $10.5(1.0)$ & $9.6(0.7)$ & $9.8(0.9)$ & $10.1(1.0)$ & $11.1(0.8)$ \\
$20-30$ & $12.2(0.9)$ & $12.7(1.0)$ & $13.4(0.6)$ & $12.3(0.6)$ & $12.9(0.5)$ \\
$25-35$ & $12.7(0.6)$ & $13.3(0.3)$ & $\underline{12.7(0.5)}$ & $12.4(0.4)$ & $13.4(0.4)$ \\
$30-40$ & $13.7(0.7)$ & $13.4(0.5)$ & $\underline{13.3(0.3)}$ & $13.5(0.8)$ & $13.7(0.6)$ \\
$\begin{array}{llllll}\text { Response } \\
\text { curve }\end{array}$ & & & & & \\
relation- & & & & & \\
ship & Quadratic & Quadratic & Quadratic & Quadratic & Quadratic \\
$R^{2}$ & $0.95^{* *}$ & $0.97^{* *}$ & $0.95^{* *}$ & $0.96^{* *}$ & $0.97^{* *}$ \\
\hline
\end{tabular}

- Significant at $P<0.01$.

potentials of -1.2 and $-1.6 \mathrm{MPa}$ than in distilled water. Percent germination of Cheyenne and Lometa seeds was significantly $(P<0.05)$ lower than that of controls at $-0.8 \mathrm{MPa}$ and more negative water potentials.

Table 3. Means and standards deviations (in parentheses) for the effect of reduced water potentials (MPa) on percent germination, corrected germination rate index (CGRI), root length $(\mathrm{mm})$, and shoot longth $(\mathrm{mm})$ of 3 varieties of Indiangrass at $15-25^{\circ} \mathrm{C}$ (12 hours light-12 hours dark). Underlined means are not significantly different $(P>0.05)$ from controls (0 MPa) according to Fisher's protected LSD.

\begin{tabular}{|c|c|c|c|c|}
\hline \multirow{2}{*}{$\begin{array}{l}\text { Variety and } \\
\text { water } \\
\text { potential }\end{array}$} & \multicolumn{4}{|c|}{ Characteristic } \\
\hline & $\begin{array}{c}\% \\
\text { Germination }\end{array}$ & CGRI & $\begin{array}{l}\text { Root } \\
\text { length }\end{array}$ & $\begin{array}{l}\text { Shoot } \\
\text { length }\end{array}$ \\
\hline & $-\%-$ & & & $-m m-$ \\
\hline $\begin{array}{r}0 \\
-0.4\end{array}$ & $\begin{array}{l}31(4) \\
30(6)\end{array}$ & $\begin{array}{r}12.5(1.9) \\
9.0(0.8)\end{array}$ & $\begin{array}{l}43(16) \\
29(21)\end{array}$ & $\begin{array}{l}47(15) \\
30(15)\end{array}$ \\
\hline $\begin{array}{l}-0.8 \\
-1.2 \\
-1.6\end{array}$ & $\begin{array}{c}24(8) \\
5(5) \\
0\end{array}$ & $\begin{array}{c}6.2(0.4) \\
5.1(0.2) \\
-\end{array}$ & $\begin{array}{l}18(13) \\
14(7)\end{array}$ & $\begin{array}{l}20(13) \\
10(5)\end{array}$ \\
\hline $\begin{array}{l}\text { Response cur } \\
\text { relationship } \\
R^{2} \\
\text { Lometa }\end{array}$ & $\begin{array}{l}\text { Quadratic } \\
0.62^{* *}\end{array}$ & $\begin{array}{l}\text { Quadratic } \\
0.87^{* *}\end{array}$ & $\begin{array}{c}\text { Linear } \\
0.33^{* *}\end{array}$ & $\begin{array}{c}\text { Linear } \\
0.48 *\end{array}$ \\
\hline $\begin{array}{r}0 \\
-0.4\end{array}$ & $\begin{array}{l}44(5) \\
38(8)\end{array}$ & $\begin{array}{r}10.8(1.2) \\
9.1(0.4)\end{array}$ & $\begin{array}{l}54(15) \\
36(16)\end{array}$ & $\begin{array}{l}53(10) \\
35(21)\end{array}$ \\
\hline $\begin{array}{l}-0.8 \\
-1.2 \\
-1.6\end{array}$ & $\begin{array}{l}27(14) \\
5(6) \\
0\end{array}$ & $\begin{array}{c}6.0(0.3) \\
5.1(0.3) \\
-\end{array}$ & $\begin{array}{l}21(9) \\
12(6) \\
-\end{array}$ & $\begin{array}{l}20(13) \\
10(6)\end{array}$ \\
\hline $\begin{array}{l}\text { Response cur } \\
\text { relationship } \\
R^{2} \\
\text { Tejas }\end{array}$ & $\begin{array}{l}\text { Quadratic } \\
0.68 * *\end{array}$ & $\begin{array}{c}\text { Linear } \\
0.88 * *\end{array}$ & $\begin{array}{l}\text { Linear } \\
0.61^{* *}\end{array}$ & $\begin{array}{c}\text { Linear } \\
0.55^{* *}\end{array}$ \\
\hline $\begin{array}{r}0 \\
-0.4\end{array}$ & $\begin{array}{l}46(9) \\
47(6)\end{array}$ & $\begin{array}{l}13.7(1.8) \\
10.9(0.6)\end{array}$ & $\begin{array}{l}48(10) \\
44(19)\end{array}$ & $\begin{array}{l}52(19) \\
42(20)\end{array}$ \\
\hline-0.8 & $40(9)$ & $7.8(0.8)$ & $29(9)$ & 38(11) \\
\hline-1.2 & $17(10)$ & $5.4(0.3)$ & $15(9)$ & $18(11)$ \\
\hline-1.6 & 0 & - & - & - \\
\hline $\begin{array}{l}\text { Response cur } \\
\text { relationship } \\
R^{2}\end{array}$ & $\begin{array}{l}\text { Quadratic } \\
0.67^{* *}\end{array}$ & $\begin{array}{c}\text { Linear } \\
0.91^{* *}\end{array}$ & $\begin{array}{c}\text { Linear } \\
0.52^{* *}\end{array}$ & $\begin{array}{c}\text { Linear } \\
0.37^{* *}\end{array}$ \\
\hline
\end{tabular}

**Significant at $P<0.01$. 
Corrected germination rate index of Cheyenne decreased quadratically with decreasing water potential and decreased linearly with decreasing water potential for seeds of the Lometa and Tejas varieties (Table 3). CGRI of all 3 varieties at $-0.4 \mathrm{MPa}$ and lower water potentials was lower than that of controls.

Root and shoot length of each variety decreased linearly with decreasing water potential (Table 3). Tejas appeared better adapted for seedling development at low water potentials than Cheyenne and Lometa Indiangrass. Root length of Tejas seedlings was similar to that of controls at $-0.4 \mathrm{MPa}$. Tejas shoot length was similar to that of controls at -0.4 and $-0.8 \mathrm{MPa}$. Roots and shoots of Cheyenne and Lometa seedlings were shorter than those of controls at $-0.4 \mathrm{MPa}$ and lower water potentials.

Cheyenne and Tejas seeds exhibited a quadatic decrease in percent germination with increasing $\mathrm{NaCl}$ concentration, while percent germination of Lometa seeds decreased linearly (Table 4).

Table 4. Means and standard deviations (in parentheses) for the effect of sodium chloride concentration (mol liter-1 on percent germination, corrected germination rate index (CGRI), root lenth $(\mathrm{mm})$, and shoot length $(\mathrm{mm})$ of 3 varieties of Indiangrass at 15-25 $\mathrm{C}$ (12 hours light-12 hours dark). Underlined means are not significantly different $(P>0.05)$ from controls $(0 \mathrm{MPa})$ according to Fisher's protected LSD.

\begin{tabular}{|c|c|c|c|c|}
\hline \multirow{2}{*}{$\begin{array}{l}\text { Variety and } \\
\text { sodium } \\
\text { chloride level }\end{array}$} & \multicolumn{4}{|c|}{ Characteristic } \\
\hline & $\begin{array}{c}\% \\
\text { Germination }\end{array}$ & CGRI & $\begin{array}{l}\text { Root } \\
\text { length }\end{array}$ & $\begin{array}{l}\text { Shoot } \\
\text { length }\end{array}$ \\
\hline Cheyenne & $-\%$ & & $-\mathrm{mm}-$ & $-\mathrm{mm}-$ \\
\hline $\begin{array}{l}0 \\
0.06\end{array}$ & $\begin{array}{l}33(5) \\
31(6)\end{array}$ & $\begin{array}{l}14.3(1.7) \\
11.5(2.8)\end{array}$ & $\begin{array}{l}32(9) \\
46(10)\end{array}$ & $\begin{array}{l}46(15) \\
51(13)\end{array}$ \\
\hline 0.12 & $\overline{25}(7)$ & $9.1(0.6)$ & $32(7)$ & $\overline{35}(8)$ \\
\hline $\begin{array}{l}0.18 \\
0.24\end{array}$ & $\begin{array}{r}18(7) \\
5(3)\end{array}$ & $\begin{array}{l}6.6(0.7) \\
5.5(0.8)\end{array}$ & $\begin{array}{l}\overline{21}(6) \\
11(4)\end{array}$ & $\begin{array}{r}20(8) \\
7(3)\end{array}$ \\
\hline $\begin{array}{l}\text { Response curve } \\
\text { relationship } \\
R^{2} \\
\text { Lometa }\end{array}$ & $\underset{0.78^{* *}}{\text { Quadratic }}$ & $\begin{array}{l}\text { Linear } \\
0.81 * *\end{array}$ & $\begin{array}{c}\text { Quadratic } \\
0.62^{*}\end{array}$ & $\begin{array}{c}\text { Quadratic } \\
0.71^{* \bullet}\end{array}$ \\
\hline $\begin{array}{l}0 \\
0.06\end{array}$ & $\begin{array}{l}37(11) \\
30(4)\end{array}$ & $\begin{array}{r}12.1(3.0) \\
9.3(0.9)\end{array}$ & $\begin{array}{l}44(11) \\
44(6)\end{array}$ & $\begin{array}{l}47(12) \\
41(10)\end{array}$ \\
\hline 0.12 & $19(5)$ & $7.3(0.4)$ & $40(8)$ & $32(8)$ \\
\hline $\begin{array}{l}0.18 \\
0.24\end{array}$ & $\begin{array}{l}5(4) \\
1(1)\end{array}$ & $\begin{array}{l}6.0(0.8) \\
5.0(0)\end{array}$ & $\begin{array}{c}17(10) \\
5(2)\end{array}$ & $\begin{array}{c}17(10) \\
6(3)\end{array}$ \\
\hline $\begin{array}{l}\text { Response curve } \\
\text { Relationship } \\
\boldsymbol{R}^{2} \\
\text { Tejas }\end{array}$ & Linear & $\begin{array}{c}\text { Linear } \\
0.69 * *\end{array}$ & $\begin{array}{l}\text { Quadratic } \\
0.68^{* *}\end{array}$ & $\begin{array}{c}\text { Linear } \\
0.64^{* *}\end{array}$ \\
\hline $\begin{array}{l}0 \\
0.06\end{array}$ & $\begin{array}{l}47(7) \\
42(8)\end{array}$ & $\begin{array}{l}14.8(1.4) \\
13.3(1.9)\end{array}$ & $\begin{array}{l}42(11) \\
40(6)\end{array}$ & $\begin{array}{l}69(16) \\
57(12)\end{array}$ \\
\hline 0.12 & $\underline{44}(10)$ & $10.4(1.3)$ & $35(6)$ & $40(14)$ \\
\hline $\begin{array}{l}0.18 \\
0.24\end{array}$ & $\begin{array}{l}31(9) \\
11(6)\end{array}$ & $\begin{array}{l}7.0(0.7) \\
5.7(0.6)\end{array}$ & $\begin{array}{l}29(7) \\
13(5)\end{array}$ & $\begin{array}{l}24(4) \\
13(6)\end{array}$ \\
\hline $\begin{array}{l}\text { Response curve } \\
\text { relationship } \\
R^{2}\end{array}$ & $\begin{array}{l}\text { Quadratic } \\
0.74 *\end{array}$ & $\begin{array}{c}\text { Linear } \\
0.88^{* *}\end{array}$ & $\begin{array}{l}\text { Quadratic } \\
0.69 * *\end{array}$ & $\begin{array}{c}\text { Linear } \\
0.79^{* *}\end{array}$ \\
\hline
\end{tabular}

* Significant at $\mathbb{A}<0.01$.

Percent germination of Cheyenne and Lometa seeds was lower than that of controls at 0.12 mol liter $^{-1}$ and greater concentrations. Percent germination of Tejas seeds was reduced at 0.18 and 0.24 mol liter ${ }^{-1}$.

Corrected germination rate index of all varieties decreased linearly with increasing $\mathrm{NaCl}$ concentration (Table 4). CGRI of all varieties was lower than controls at all $\mathrm{NaCl}$ concentrations.

Root lengths of all varieties responded quadratically to increasing $\mathrm{NaCl}$ concentrations (Table 4). Cheyenne and Lometa roots were shorter than those of controls at concentrations of 0.18 and 0.24 mol liter $^{-1}$. Roots of Tejas seedlings were shorter than those of controls at all concentrations greater than $0.06 \mathrm{~mol} \mathrm{liter}^{-1}$

Shoot length of Cheyenne seedlings responded quadratically to increasing $\mathrm{NaCl}$ concentration and shoots of Lometa and Tejas seedlings decreased linearly with increasing concentration (Table 4). Shoot length of Cheyenne and Lometa seedlings was reduced by $\mathrm{NaCl}$ concentrations of $0.12 \mathrm{~mol} \mathrm{liter}^{-1}$ or more compared to controls. Shoot length of Tejas was reduced by all $\mathrm{NaCl}$ concentrations.

\section{Discussion}

The optimum temperatures for percent germination of Indiangrass were similar to those reported for little bluestem [Schizachyrium scoparium (Michx.) Nash], a species with which Indiangrass often grows in association. The optimum temperature for percent germination of little bluestem is $16.5-27^{\circ} \mathrm{C}$ (16 hours-8 hours) (Sabo et al. 1979). The optimum temperature for percent germination was lower than that of brownseed paspalum (Paspalum plicatulum Michx.), a species that commonly grows in association with Indiangrass in southern Texas. The optimum temperatures for percent germination of brownseed paspalum sources from south Texas range from $20-30$ to $30-40^{\circ} \mathrm{C}$ (12 hours-12 hours) (Flenniken and Fulbright 1987).

Monthly average daily minimum and maximum air temperatures in the optimum temperature range for percent germination of Lometa occur most frequently in southern coastal Texas in March, April, May, and October (NOAA 1972). Optimum temperatures for CGRI of Lometa occur from April to October. Planting in April or May would possibly favor percent germination and germination rate of Lometa. Spring planting might also be desirable because May is a period of relatively high rainfall.

Tejas seeds appeared to be better adapted for germination and seedling development at low water potentials than Cheyenne or Lometa seeds. Tejas seeds also appeared better adapted for germination in the range of salt concentrations tested than the other varieties. Although Tejas seeds appeared adapted for optimum germination at higher salt concentrations than the other varieties, Lometa and Cheyenne seedlings produced greater root and shoot growth at higher salt concentrations than Tejas.

The osmotic potential of a 0.18 mol liter $^{-1}$ solution of $\mathrm{NaCl}$ is about $0.81 \mathrm{MPa}$. Effects of the $\mathrm{NaCl}$ solutions on Cheyenne and Tejas seeds were possibly more related to osmotic effects than toxic effects of $\mathrm{NaCl}$ because germination percentages and rates were similar for the $0.18 \mathrm{~mol}_{\text {liter }}^{-1} \mathrm{NaCl}$ solution and the $0.8 \mathrm{MPa}$ PEG solution. Percent germination of Lometa Indiangrass was lower in $\mathrm{NaCl}$ solutions than in PEG solutions with similar water potential, indicating possible toxic effects of the salt.

\section{Literature Cited}

Aswociation of Omeial Seed Analyats. 1970. Rules for testing seeds. Proc. Assoc. Official Seed Analysts 60:1-116.

Berkat, O., and D.D. Briske. 1982. Water potential evaluation of 3 germination substrates utilizing polyethylene glycol 20,000. Agron. J. 74:518-521.

Flenniken, K.S., and T.E. Fulbright. 1987. Effects of temperature, light, and scarification on germination of brownseed paspalum seeds. J. Range Manage. 40:175-179.

Grabe, D.F. (edit.). 1970. Tetrazolium testing handbook. Cont. no. 19 to the Handbook on Seed Testing. Association of Official Seed Analysts.

Hsu, F.H., C.J. Nelson, and A.G. Matches. 1985. Temperature effects on germination of warm-season forage grasses. Crop Sci. 25:215-220.

Lorenz, D.G., and R.B. Heizer. 1982. Registration of 'Lometa' Indiangrass. Crop Sci. 22:686.

Mazuire, J.D. 1962. Speed of germination- Aid in selection and evaluation for seedling emergence and vigor. Crop Sci. 2:176-177.

Michel, B.E. 1983. Evaluation of the water potentials of polyethylene glycol 8000 both in the presence and absence of other solutes. Plant Physiol. 72:66-70.

National Oceanic and Atmospheric Administration. 1972. Climatological summary, Kingsville, Texas. Bureau of Business Research, The University of Texas, Austin. 
Petersen, R.G. 1985. Design and analysis of experiments. Marcel Dekker, Inc., New York.

Sabo, D.G., G.V.Johnson, W.C. Martin, and E.F. Aldon. 1979. Germination of 19 species of arid land plants. USDA Forest Serv. Res. Pap. RM-210. USDA Forest Serv., Rocky Mnt. Forest and Range Exp. Sta., Fort Collins, Colo.

Snedecor, G.W., and W.G. Cochran. 1967. Statistical methods, 6th edit. The Iowa State University Press, Ames.
Young, J.A., R.A. Evans, R.E. Eckert, Jr., and R.D. Eadja. 1981. Germination-temperature profiles for Idaho and sheep fescue and Canby bluegrass. Agron. J. 73:716-720.

Yount, J.A., R.A. Evans, B. Roundy, and G. Cluff. 1983. Moisture stress and seed germination. USDA-ARS, ARM-W-36. USDA, Oakland, Calif. 